\title{
VYBRANÉ PRÁVNÍ OTÁZKY SOUVISEJÍCÍ S POSTAVENÍM JERUZALÉMA JAKOŽTO HLAVNÍHO MĚSTA STÁTU゚ IZRAEL A PALESTINA
}

\author{
VERONIKA D'EVEREUX
}

\begin{abstract}
Selected Legal Issues Related to the Status of Jerusalem as the Capital City of the State of Israel and the State of Palestine

The city of Jerusalem was meant to be subject to the United Nations direct administration of the "corpus separatum" regime according to the Resolution 181 (II). Due to the events of the first Arab-Israeli war, Jerusalem was de facto divided between the newly-created State of Israel and Jordan. After the events of the Six-Day War, the State of Israel occupied East Jerusalem and thus expanded its influence on the city as a whole. The Palestinian State, with its capital, East Jerusalem, was admitted to the UN as a non-member state with observer status. Alongside with the embassies relocation plan, Jerusalem might be recognized as the capital of Israel.
\end{abstract}

Keywords: capital city; de facto partition; military occupation; embassies relocation plan

Klíčová slova: hlavní město; de facto rozdělení; vojenská okupace; plán na přestěhování zastupitelských úřadů

DOI: $10.14712 / 23366478.2019 .42$

\section{1. ÚVOD}

Město Jeruzalém je aktéry izraelsko-palestinského konfliktu považováno de facto za hlavní město obou států a je tím i předmětem sporu mezi těmito stranami. Postavení Jeruzaléma je zároveň i nesnadno uchopitelné z pohledu mezinárodního práva, přičemž není možné ve stručnosti v rozsahu tohoto prííspěvku vyjmenovat všechny právní otázky související s jeho statusem.

Protichůdné nároky teritoriální suverenity vůči městu Jeruzalému státy Izrael a Palestina jsou odůvodňovány především historickými, náboženskými, morálními a v neposlední řadě i politickými aspekty, lze ovšem nalézt i odůvodnění na základě právních pramenů, jimž je tento př́spěvek věnován.

$Z$ toho důvodu se autorka zaměří na některé vybrané otázky a ve svém př́spěvku se zabývá především právními dějinami před vznikem státu Izrael, statusem Jeruzaléma v období od vzniku státu Izrael do šestidenní války, právními aspekty souvisejícími s pozdějšími událostmi, izraelskou okupací Východního Jeruzaléma (a Západního bře- 
hu) po šestidenní válce, nároky na východní část Jeruzaléma v souvislosti se vznikem státu Palestina a v neposlední řadě i aktuálními otázkami souvisejícími s uznáním Jeruzaléma hlavním městem státu Izrael společně s plánovaným přesunem zastupitelských úřadů z Tel Avivu do západní části Jeruzaléma.

\section{SOUVISEJÍCÍ PRÁVNÍ UDÁLOSTI PŘED VZNIKEM STÁTU IZRAEL}

V průběhu správy vykonávané Osmanskou ř́ší, jež od roku 1517 prováděla teritoriální jurisdikci nejen vǔči Jeruzalému, ${ }^{1}$ ale zároveň i vưči území dnešních států Izrael a Palestina jakožto jednoho celku, ${ }^{2}$ bylo vytvořeno několik dohod ve vztahu ke kostelům a svatým místům v Jeruzalémě a Betlémě z důvodu trvajících sporů mezi místními křest’anskými církevními komunitami, ř́msko-katolickou, řecko-pravoslavnou a arménskou. Turecká vláda přijala v roce 1757 a 1852 vyhlášky, ${ }^{3}$ které upravovaly oprávnění těchto komunit vůči dotčeným místům, tyto vyhlášky upravovaly režim těchto míst jakožto správu status quo ${ }^{4}$ vykonávanou $a b$ antiquo prŕslušnými církvemi. Úprava míst status quo se zákazem provádění jakýchkoliv změn vǔči těmto místům ${ }^{5}$ získala v roce 1878 mezinárodní uznání v čl. 62 Berlínské úmluvy uzavřené mezi Velkou Británií, Rakousko-Uherskem, Francií, Pruskem, Itálií, Ruskem a Osmanskou říší. ${ }^{6}$ Berlínská úmluva potvrzovala ustanovení Pařížské úmluvy ${ }^{7} \mathrm{z}$ roku 1856 uzavřené mezi Velkou Británií, Francií, Osmanskou říší, Sardinií a Ruskem, která ve svém článku 9 uznávala výše zmiňovanou vyhlášku tureckého sultána z roku 1852 upravující církevní správu svatých míst v Jeruzalémě a Betlémě.

V souvislosti s plánem Světové sionistické organizace bylo na konci 19. století iniciováno a podporováno přistěhovalectví evropských Židů za účelem vytvoření nové domoviny a návratu $\mathrm{k}$ původním kořenům tohoto národa. Centrem zájmu židovských imigrantů byl logicky i Jeruzalém, který byl hojně osidlován a již v 80 . letech 19 . století

ČEJKA, M. Israel a Palestina. Brno: Barrister and Principal, spol. s. r. o., 2015, s. 18.

2 CASSESE, A. Legal Consideration on the International Status of Jerusalem. The Palestine Yearbook of International Law. Leiden: Brill Nijhoff, 1986, č. 3, s. 16.

3 Apendix 3, Imperial Firman of February 1852, Concerning the Christian Holy Places. In: The Israeli Palestinian Conflict, An Interactive Database (beta) [online]. Tel Aviv, 2015, s. 178-180 [cit. 17. 2. 2019]. Dostupné na: https://ecf.org.il/media_items/1509.

4 CATTAN, H. Jerusalem. London: Croom Helm, 1981, s. 27-28.

5 BARON, Ch. B. The International Legal Status of Jerusalem. In: Touro International Law Review [online]. New York: Touro College, 1998, s. 2 [cit. 23. 12. 2018]. Dostupné na: http://www.mclaughlinstern.com /docs/publications/The-International-Legal-Status-of-Jerusalem.pdf.

6 Treaty of Berlin between Great Britain, Austria - Hungary, France, Germany, Italy, Russia and Turkey, July 13, 1878. In: The Israeli Palestinian Conflict, An Interactive Database (beta) [online]. Tel Aviv, 2015, s. 4 [cit. 17. 2. 2019]. Dostupné na: https://ecf.org.il/media_items/1489.

7 Tamtéž, s. $3-4$. 
tvořili židovští přistěhovalci reálnou a trvalou většinu ${ }^{8}$ vedle arabských a křest’anských obyvatel. $^{9}$

K ukončení správy Jeruzaléma a území dnešních států Izrael a Palestina Osmanskou řiší došlo ke konci roku 1917 po porážce armády Osmanské říše Velkou Británií. Již v roce 1916 byla uzavřena dohoda mezi dvěma členy Trojdohody, Velké Británie a Francie, s pozdějším souhlasem Ruska, známá jako Sykes Picotova dohoda, dle níž ve vztahu $\mathrm{k}$ Palestině pro př́pad porážky Osmanské ríśš v první světové válce mělo dojít k uznání nezávislého arabského státu nebo konfederace a dále bylo dojednáno rozdělení vlivu, záštity a administrativní správy území Osmanské říše zúčastněnými státy Trojdohody. Palestinské prŕstavy Haifa a Akko by dle této dohody spadaly pod správu Velké Británie a svatá místa $\mathrm{v}$ Palestině by byla předmětem mezinárodní správy. ${ }^{10} \mathrm{Na}$ druhé straně dne 2. 11. 1917 lord Balfour ${ }^{11}$ jménem britského válečného kabinetu vydal prohlášení ve smyslu náklonnosti vlády Jeho Veličenstva k vytvoření národního domova pro židovský národ v Palestině s ujištěním o vynaložení nejvyššího úsilí k dosažení tohoto cíle s tím, že nebudou učiněny kroky, které by způsobily újmu občanských či náboženských práv stávajících nežidovských obyvatel Palestiny, jejich právní postavení a politický status bude stejný jako ten, který požívají Židé v ostatních zemích. ${ }^{12}$ Tato část Balfourovy deklarace ${ }^{13}$ byla později zahrnuta do dokumentů vztahujících se k ustanovení mandátu Palestina. ${ }^{14}$

8 Srov. HERZOG, Ch. Arabsko-Izraelské války. Praha: Nakladatelství Lidové noviny, 2008, s. 12. Quigley naopak uvádí, že ještě v roce 1900 Židé tvořili jen přibližně polovinu obyvatel Jeruzaléma, QUIGLEY, J. The Legal Status of Jerusalem under International Law. The Turkish Yearbook [online], 1994, vol. 24, s. 12 [cit. 23. 12. 2018]. Dostupné na: http://dergiler.ankara.edu.tr/dergiler/44/681/8664.pdf, BEN-SASSON, H. H. A History of the Jewish People. Cambridge: Harvard University Press, 1976, s. 916-917.

Odlišné údaje přejímá Jewish Virtual Library, uvádí data z izraelského Ústředního statistického úřadu, dle kterých byla židovská většina v Jeruzalémě již od roku 1844, viz Democraphics of Israel: Population of Jerusalem (1844 - present). In: Jewish Virtual Library, Project of Aice [online], 2019 [cit. 17. 2. 2019]. Dostupné na: https://www.jewishvirtuallibrary.org/population-of-jerusalem-1844-2009.

Dle Johnsona došlo k formování těsné židovské většiny již v průběhu let 1827-1839, v tomto období vzrostl počet židovských obyvatel Jeruzaléma z 550 na 5500 srov. JOHNSON, P. Dějiny židovského národa. Brno: Rozmluvy. 1995. s. 312.

Pozn. autorka si je plně vědoma, že uvádí jako př́klady jen některé náhodně vybrané zdroje vycházející z dostupných statistik, domnívá se, že není podstatou tohoto článku zabývat se komparací veškerých dostupných statistických dat o počtu obyvatel Jeruzaléma, nicméně chápe důležitost těchto údajů a príklání se v rámci tohoto možného období, v němž došlo $\mathrm{k}$ formování židovské většiny obyvatel Jeruzaléma ke druhé polovině uvedeného intervalu, a sice z důvodu větši jistoty tohoto tvrzení na rozdíl od př́padného přiklonění se $\mathrm{k}$ názorům, které datují židovskou většinu $\mathrm{k}$ dřívějšímu datu.

9 MRÁZEK, J. Právní postavení Palestiny a otázka jejího uznání jako státu. Právnik, 2012, roč. 151, č. 8, s. 845.

10 Srov. Sykes Picot Agreement In: Encyclopaedia Britannica [online], 2019 [cit. 18. 2. 2019]. Dostupné na: https://www.britannica.com/event/Sykes-Picot-Agreement.

11 Srov. CATTAN, H. Palestine. The Arabs and Israel. Search for Justice. Londýn: Longman, 1969, s. 13-16.

12 The Levy Commission Report on the Legal Status of Building in Judea and Samaria. In: Pro Con [online]. Santa Monica, 2018 [cit. 18. 2. 2019], s. 10. Dostupné na: https://israelipalestinian.procon.org/sourcefiles /The-Levy-Commission-Report-on-the-Legal-Status-of-Building-in-Judea-and-Samaria.pdf.

13 Srov. TSCHIRGI In: BAHCHELI, T. - BARTMANN, B. - SREBRNIK, H. De Facto States. The Quest for Sovereignty. New York: Taylor \& Francis, 2005, s. 191.

14 CRAWFORD, J. R. The Creation of the States in International Law. Oxford: Oxford University Press, 2006, s. 422. 
V období let 1917 až 1918 Velká Británie na území Palestiny uvalila vojenskou okupační správu a následně do roku 1921 civilní okupační správu a poté od roku 1922 došlo $\mathrm{k}$ vytvoření mandátní správy trvající do roku $1948 .{ }^{15}$

Mandátní a poručenská území vznikla na základě konsensu spojeneckých států a Společnosti národů ${ }^{16}$ po první světové válce na základě čl. $22^{17}$ Paktu Společnosti národů. Mandátní systém pokrýval území, kterých se vzdala Osmanská ř́še a Německo. Tato území byla rozdělena do tř́ tř́́d, mandátů „A“, „B“ a „,C“. Po druhé světové válce došlo $\mathrm{k}$ přeměně mandátních území $\mathrm{v}$ mezinárodní poručenská území na základě kapitoly XII a XIII Charty OSN. ${ }^{18}$ Poručenská území byla rozdělena na dvě třídy, a sice „obyčejná poručnická území“ pod správou Valného shromáždění a „strategická poručnická území " pod správou Rady bezpečnosti. Oba typy poručnických území měly totožné cíle, jimiž byla podpora blaha a rozvoje obyvatel v těchto územích, jejich rozvoj směřující k samosprávě a samostatnosti. ${ }^{19}$ Poručenská území se zakládala na principu mezinárodní odpovědnosti spravujícího státu ve smyslu realizace těchto cílů, zajištění bezpečnosti prostřednictvím Paktu a Charty a jednotlivých dohod. Oba typy poručenských území dále spojovalo odmítnutí anexe koloniálních území, která náležela jednotlivým koloniálním mocnostem před světovou válkou. Namísto toho tato území měla získat samostatnost na základě principu práva na sebeurčení. Palestina byla formálně jedním z posledních mandátních a poručenských území a k ukončení mandátní správy došlo jednostrannou notifikací Velké Británie Valnému shromáždění, k níž mělo dojít nejpozději $\mathrm{k}$ datu 1. 8. 1948. ${ }^{20}$ Na mandátní a poručenská území lze nahlížet jako na území, která ještě nemají schopnost samosprávy s tím, že do budoucna tato území nabydou samostatnosti a suverenity, přičemž pojem suverenita může být synonymem pro nezávislost, konečnou pravomoc disponovat se svým územím. ${ }^{21}$ Suverenitou státu v obecné rovině je možno rozumět též výlučné ovládání svého území, výkon veřejné moci vůči obyvatelstvu a věcem, uplatňování územní výsosti a disponování hospodářským, vojenským a jiným potenciálem. Suverenitou státu lze také rozumět státní moc, která je

15 GINAT, A. British Mandate for Palestine. In: International Encyclopedia of the First World War, Freie Universität Berlin [online]. Berlin, 2018 [cit. 17. 2. 2019]. Dostupné na: https://encyclopedia.1914-1918 -online.net/article/british_mandate_for_palestine.

16 SCOBBIE, I. - HIBBIN, A. The Israel-Palestine Conflict in International Law: Territorial Issues. In: U.S./ Middle East Project [online], 2019 [cit. 17. 2. 2019]. Dostupné na: https://www.soas.ac.uk/lawpeacemideast/publications/file60534.pdf.

17 Mírová smlouva mezi mocnostmi spojenými a sdruženými a Německem a Protokol podepsaný ve Versailles dne 28. června 1919. 217/1919 Sb., znění účinné od 10. 1. 1920 do 1.1. 1945 [online], 2019 [cit. 17. 2. 2019]. Dostupné na: https://www.beck-online.cz/bo/chapterview-document.seam?documentId=onrf6mjzgiyv6mrrg4wta. Alternativně lze nalézt český překlad Paktu o Společnosti národů např. In: SCHELLE, K. Moderní dějiny státu a práva v dokumentech. Brno: Masarykova univerzita, 1992, s. 53-61.

18 Charta Organizace spojených národů a Statut mezinárodního soudního dvora. In: POTOČNÝ, M. - ONDŘEJ, J. Obecné mezinárodní právo v dokumentech. Praha: C. H. Beck, 2000, s. 207-220.

19 CRAWFORD, c. d., s. 566.

20 UNITED NATIONS SYSTEM, GENERALASSEMBLY WORKING PAPER. The Question of Palestine [online], 2007 [cit. 28. 4. 2019]. Dostupné na: https://www.un.org/unispal/document/un-palestine-commission -termination-of-the-mandate-withdrawal-of-british-forces-transfer-of-power-to-un-palestine-commission -working-paper/.

${ }^{21}$ CRAWFORD, c. d., s. 569. D'AMATO, A. Israel's Borders under International Law. In: Northwestern University School of Law [online], 2007 [cit. 23. 12. 2018]. Dostupné na: https://papers.ssrn.com/sol3 /papers.cfm?abstract_id $=956143$. 
na daném prostoru nejvyšší, vůči jiným suverénům nezávislá a eliminující každou jinou konkurující moc na daném území. Navenek není suverenita státu omezena než vlastním mocenským potenciálem, uvnitř je chráněna vnitrostátním právem a je chráněna mezinárodním právem, především co do povinnosti států nezasahovat a nevměšovat se do vnitřních věcí jiného státu. ${ }^{22}$

Mezi právně relevantní ${ }^{23}$ prameny týkající se uspořádání území Palestiny vč. území Jeruzaléma lze řadit čl. 22 Paktu o Společnosti národů, ${ }^{24}$ který uvádí, že určitá území oddělená od Turecka by mohla být prozatímně uznána coby nezávislé národy s předmětem administrativní správy a podpory mandatáře, a to po dobu, dokud nebudou schopny samostatnosti.

V čl. 95 mírové smlouvy ze Sevres v Turecku z 10. 8.1920 je aplikováno ustanovení čl. 22 Paktu o Společnosti národů, dle něhož měla být budoucí správa Palestiny realizována prostřednictvím dohody mezi spojenými vítěznými mocnostmi, které zvolí mandatáře. Mandatář bude zodpovědný za výkon deklarace britské vlády z 2. 11. 1917, tj. Balfourovy deklarace, jež byla spojenci přijata s účelem umožnění vzniku Palestiny coby národního domova pro židovský národ. Vlivem revoluce v Turecku mírová dohoda ze Sevres nikdy nebyla ratifikována.

Společnost národů nicméně dne 24. 6. 1922 přijala podmínky britského mandátu Palestina s účinností k 29. 9. 1923 po podpisu členy Společnosti národů. Stalo se tak ještě před tureckou ratifikací smlouvy z Lausanne, jež nahrazovala smlouvu ze Sevres, která nikdy nevešla v platnost. Smlouva z Lausanne stanovila hranice Turecka tak, jak jsou do dnešní doby, neodkazovala ovšem ani na čl. 22 Paktu Společnosti národů ani na Balfourovu deklaraci. V článku 16 smlouvy z Lausanne ${ }^{25}$ ze dne 24. 7. 1923 Turecko činí jednostranné prohlášení, jímž se zříká veškerých teritoriálních nároků v oblasti provincie Palestiny. V tomto prohlášení ovšem není specifikováno, v čí prospěch se tohoto území zř́ká. $Z$ toho důvodu nelze jednoznačně určit právního nástupce, dle této smlouvy bude status území pro futuro upraven dotčenými stranami, bez další konkretizace zúčastněných stran.

V roce 1922 byl vytvořen v souvislosti s čl. 22 Paktu o Společnosti národů26 mandátní režim pro území dnešního státu Izrael a Palestina, který měl trvat do doby, dokud dotčené území dosáhne plné samostatnosti a schopnosti samosprávy. Úprava Mandátu Palestina vč. inkorporované Balfourovy deklarace ovšem toliko rámcově stanovila vy-

22 ČEPELKA, Č. - ŠTURMA, P. Mezinárodní právo veřejné. Praha: C. H. Beck, 2008, s. 50-52.

23 V této souvislosti existují i další dokumenty, kterými jsou politická prohlášení nemající vliv na právní status provincie Palestiny, jsou jimi např. korespondence mezi vysokým britským komisařem v Egyptě sirem Henry McMahonem a šárifem Husajnem, dohoda mezi Weiymannem a Fajsalem z 3. 1. 1919. Po vyhnání osmanských vojsk vykonávala Velká Británie fakticky státní moc nad provincií Palestina, ovšem v pozici válečné okupační síly dle čl. 42 a 56 Řádu války pozemní z roku 1907, viz ČEJKA, M. Izrael a Palestina, s. 32-38.

24 Mirová smlouva mezi mocnostmi spojenými a sdruženými a Německem a Protokol podepsaný ve Versailles dne 28. června 1919, 217/1919 Sb., znění účinné od 10.1. 1920 do 1. 1. 1945, c. d.

25 Treaty of Peace with Turkey and Other Instruments (1923) [online], 1923 [cit. 28. 3. 2019]. Dostupné na: https://www.qdl.qa/en/archive/81055/vdc_100000001491.0x00028f.

26 Mírová smlouva mezi mocnostmi spojenými a sdruženými a Německem a Protokol podepsaný ve Versailles dne 28. června 1919, 217/1919 Sb., znění účinné od 10. 1. 1920 do 1. 1. 1945 [online], 2019 [cit. 17. 2. 2019]. Dostupné na: https://www.beck-online.cz/bo/chapterview-document.seam?documentId $=$ onrf6mjzgiyv6mrrg4wta. 
tvoření podmínek pro židovské přistěhovalectví a realizaci možnosti trvalého usídlení na dotčeném území, ${ }^{27}$ stran statusu města Jeruzaléma jako celku ovšem neobsahovala žádnou specifickou úpravu. Ustanovením Mandátu Palestina byl stanoven ve vztahu k Jeruzalému režim přístupu ke „svatým místům“ v Palestině, tedy i k některým lokalitám v Jeruzalémě. ${ }^{28}$

V období let 1922-1948 vykonávala správu Mandátu Palestina Velká Británie, výkon správy měl směřovat k rozvoji území k blahu jeho obyvatel, dokud nebude vytvořena jiná dohoda mezi Společností národů, potažmo od roku 1946 Organizací spojených národů a správcem mandátu. Mandatář nebyl nositelem územní suverenity vůči mandátnímu území, pravomoc nakládat s jakoukoliv částí území v rámci mandátu měla pouze Společnost národů a poté její nástupce Organizace spojených národů. ${ }^{29}$

V rámci mandátní správy byla Velkou Británií přijata 10. 8. 1922 právní úprava s názvem Palestine Order in Council pro fungování Palestiny, tato úprava svou povahou mohla připomínat ústavu. Zahrnovala úpravu moci výkonné, zákonodárné i soudní a dále stanovila některé další oblasti, napřr. úřad Vysokého komisaře v čele palestinské vlády, upravovala užití některých britských legislativních aktů na území Mandátu Palestiny a v neposlední řadě stanovila v části osmé některá obecná pravidla týkající se úředních jazyků, jazykových práv a náboženského vyznání. ${ }^{30} \mathrm{~V}$ letech 1922 až 1948 byl Jeruzalém jedním ze správních okrsků Palestiny, oficiálním administrativním, správním, vládním a v neposlední řadě i politickým centrem, jeho status odpovídal postavení hlavního města.

\section{3. (NE)REALIZOVANÝ PLÁN OSN NA INTERNACIONALIZACI JERUZALÉMA}

Organizace spojených národů prostřednictvím rezoluce Valného shromáždění 181 (II) přijala 29. 11. 1947 plán zahrnující internacionalizaci Jeruzaléma ${ }^{31}$ $\mathrm{z}$ důvodu, aby se toto město nestalo hlavním městem států, které na území Mandátu Palestina později měly vzniknout. Myšlenka vytvoření mezinárodní správy Jeruzaléma byla s ohledem na předchozí vývoj svým způsobem novátorská, neodpovídala tedy praxi v průběhu mandátní správy.

27 Srov. Convention Great Britain - Palestine. Washington, DC: Secretary of State [online], 3. 12. 1924 [cit. 23. 12. 2018]. Dostupné na: http://www.alliedpowersholocaust.org/wp-content/uploads/2015/03/1924 -Anglo-American-Convention.pdf.

28 Mírová smlouva mezi mocnostmi spojenými a sdruženými a Německem a Protokol podepsaný ve Versailles dne 28. června 1919, 217/1919 Sb., znění účinné od 10. 1. 1920 do 1. 1. 1945, c. d.

29 CASSESE, c. d., s. 17.

30 Palestine Order in Council. In: United Nations Information System on the Palestine [online], 2019 [cit. 19. 2. 2019]. Dostupné na: https://unispal.un.org/DPA/DPR/unispal.nsf/0/C7AAE196F41AA 055052565F50054E656.

31 Resolution 181 (II). Future Government of Palestine. In: UNITED NATIONS. Official record of the second session of the General Assembly Resolutions 16 September - 29 November 1947. New York: Lake Success, 1948, s. 131-150. MRÁZEK, J. Právní postavení Palestiny a otázka jejího uznání jako státu. Právník, 2012, roč. 151 , č. 8 , s. 849-851. 
Rezoluce VS 181 (II) obsahovala návrh na rozdělení území Mandátu Palestina na dvě části, na nichž do budoucna vznikne stát židovský a stát arabský32 s tím, že Jeruzalém bude mít zvláštní postavení, nebude podléhat suverenitě žádného státu, naopak jeho správu bude vykonávat OSN samotná. ${ }^{33}$ Město mělo být ve zvláštním režimu corpus separatum $^{34}$ a s ohledem na návrh realizace vzniku budoucích státních útvarů by byl Jeruzalém zcela obklopen státem arabským. ${ }^{35}$ Podle této rezoluce mělo dojít k vytvoření zvláštní správy Jeruzaléma na základě mezinárodního práva s poručenskou radou ${ }^{36}$ Organizace spojených národů, která by byla odpovědná i za řízení v oblasti vnějších vztahů. ${ }^{37}$ Podle této rezoluce zahrnoval mezinárodní režim města Jeruzaléma taktéž nedaleký Betlém a Ein Karem. Město Jeruzalém mělo mít svou legislativní radu volenou jeho obyvateli a mělo mít kromě moci zákonodárné také právo k výběru daní. Rezoluce taktéž pamatovala na úpravu dostupnosti tzv. svatých míst a respektovala práva náboženských menšin a jejich soukromého vlastnictví, které spadalo pod ochranu Společnosti národů.

V případě, že by tento plán byl zcela naplněn, neměli by obyvatelé budoucího židovského státu, pakliže by jeho hranice byly vytvořeny tak, jak je vymezeno touto rezolucí, jinou možnost, jak navštívit Jeruzalém, než překročit hranice arabského státu a cestovat přes jeho území. Budoucí arabský stát by měl dle obecného mezinárodního práva volnost upravit svým vnitrostátním právem podmínky pro vstup cizinců na své území, která by byla omezena jen obecnou povinností státu k mezinárodní spolupráci s ostatními zeměmi. S ohledem na své zájmy a bezpečnost by arabský stát mohl odmítnout kterémukoliv jednotlivci či jakékoliv kategorii osob př́stup na své území, ${ }^{38}$ což by případně mohlo vést i k nutnosti hledání alternativního způsobu přístupu obyvatel židovského státu do Jeruzaléma a zároveň i řešení způsobu vycestování židovských obyvatel Jeruzaléma za hranice města.

Stran právních účinků rezoluce 181 (II) lze nalézt v nauce řadu různých názorů. Mezi zastánce názoru o neplatnosti této rezoluce s ohledem na vývoj událostí se řadí např. Lacy a Stone, kteří zastávají názor, že plán Valného shromáždění OSN na rozdělení území mandátu Palestina neměl právně závaznou povahu. Citovanou myšlenku lze rozvinout tím, že závaznou by se tato rezoluce hypoteticky mohla stát v případě souhlasu zúčastněných aktérů, kteří by na základě této rezoluce přistoupili k vytvoření a uzavření smlouvy, jež by představovala právně závazný akt, na jehož základě by došlo k vytvoření dvou státních útvarů tak, jak tato rezoluce vyjadřovala. Ta byla ovšem od počátku odmítnuta arabskou stranou aktem ozbrojené invaze vojsk Egypta, Iránu, Libanonu, Sýrie a Saúdské Arábie. Touto invazí odůvodňují Lacey a Stone nemožnost

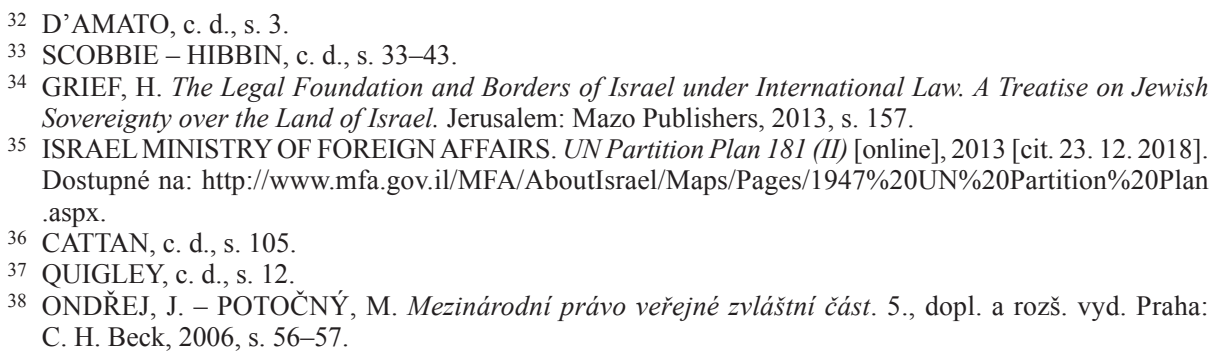

38 ONDŘEJ, J. - POTOČNÝ, M. Mezinárodni právo veřejné zvláštní část. 5., dopl. a rozš. vyd. Praha: C. H. Beck, 2006, s. 56-57. 
uskutečnit plán rezoluce 181 (II) ${ }^{39}$ a tím vysvětlují svůj názor ve smyslu, že tato rezoluce postrádala $a b$ initio obecnou závaznost. $Z$ toho dále vyvozují, že se plán rezoluce i v otázce režimu corpus separatum pro Jeruzalém stal irelevantním. ${ }^{40}$ Svůj názor dále podpírají skutečností, že OSN nikdy efektivně neimplementovala myšlenku internacionalizace Jeruzaléma, v období let 1948-1952 nevytvořila OSN príijatelný koncept corpus separatum pro obě strany, tedy jak Izrael, tak Jordánsko, a snahy o vytvoření režimu mezinárodní správy se vzdala. ${ }^{41}$

Na rozdíl od výše uvedených autorů Stona a Laceyho, podle jejichž názoru lze nahlížet na právní účinky rezoluce 181 (II) pouze z jediného úhlu pohledu, Crawford uvádí, že existují tři možné př́istupy k otázce právních účinků této rezoluce. Dle prvního prrístupu byla rezoluce vytvořena ultra vires, tedy za hranicí pravomocí Valného shromáždění OSN, druhý názor je odvozen od obecného doporučujícího charakteru rezolucí Valného shromáždění OSN a konečně třetí pojetí spočívá $v$ tom, že prostřednictvím rezoluce 181 (II) došlo k založení právně platné a efektivní dispozice vůči území Palestiny. Crawford uvádí, že orgány OSN mohly z počátku za určitých okolností (zejména na základě delegování tohoto oprávnění na konkrétní státy) vytvořit závaznou úpravu týkající se území. $\mathrm{V}$ případě Palestiny $\mathrm{k}$ tomu došlo na základě vytvoření systémů mandátních území. Podle Crawforda byla Velká Británie stále ještě v roce 1948 správcem Mandátu Palestina, demise mandatáře nebyla jednostranným aktem, naopak byla podmíněna schválením tohoto aktu Valným shromážděním. S aktem opuštění mandátu Velkou Británií o půlnoci 14.-15. 5. 1948 byla vyhlášena nezávislost státu Izrael, přičemž samotné opuštění mandátu podle Crawforda bylo v rozporu s mezinárodním právem a mezinárodní společenství mělo na tuto skutečnost reagovat prostřednictvím odvolání mandatáře, což se ovšem nestalo, naopak bylo potvrzeno britské rozhodnutí mandát opustit. ${ }^{42} \mathrm{~K}$ realizaci rezoluce 181 (II) ve smyslu vytvoření mezinárodní správy Jeruzaléma v režimu corpus separatum nedošlo, ${ }^{43}$ jak Rada bezpečnosti, tak i Velká Británie odmítly prosadit plán založený touto rezolucí. Podle Crawforda již 14. 5. 1948 Valné shromáždění upustilo od přistoupení k plánu na rozdělení Palestiny tak, jak rezoluce předpokládala, protože bylo zřejmé, že za daných okolností předcházejících události první arabsko-izraelské války, není možné realizovat účel této rezoluce. $Z$ toho důvodu byla na základě rezoluce 186 (S-2) ukončena činnost Komise OSN pro Palestinu a jako prostředník byl přizván hrabě a diplomat Folke Bernadotte, jehož postavení směřovalo k nalezení oboustranně přijatelného řešení konfliktu, ${ }^{44}$ bez ohledu na to, zda takové řešení bylo v souladu s rezolucí 181 (II).

Na konci roku 1949 v návaznosti na rezoluci 181 (II) přijalo Valné shromáždění rezoluci 303 (IV), která měla ve vztahu k Jeruzalému navázat na internacionalizaci Jeru-

39 LACEY J. - STONE, J. International Law and the Arab - Israeli Conflict. In: STONE, J. Israel and Palestine - Assault of the Law of Nations [online]. 2nd ed. Sydney: Dashing, 2003 [cit. 23. 12. 2018], s. 11. Dostupné na: http://www.strateias.org/international_law.pdf.

40 Tamtéž, s. 12.

41 Tamtéž, s. 12.

42 CRAWFORD, c. d., s. 430.

43 srov. SCOBBIE - HIBBIN, c. d., s. 43-54.

44 Tamtéž, s. 432. 
zaléma ${ }^{45}$ a vytvoření statusu corpus separatum. ${ }^{46}$ Mezi zastánce právního názoru nauky o internacionalizaci Jeruzaléma se řadí např. Cassese, který uvádí, že přes neúspěch realizace plánu rezoluce 181 (II) stát Izrael aktem vyhlášení nezávislosti uznal, že OSN bude nadále nositelem pravomoci ve smyslu rozhodování o statusu Jeruzaléma a dále že k jednání o řešení otázek souvisejících se statusem Jeruzaléma bude př́slušná OSN. ${ }^{47}$

\section{PRÁVNÍ SKUTEČNOSTI SPOJENÉ S DE FACTO ROZDĚLENÍM JERUZALÉMA}

V praxi nedošlo $\mathrm{k}$ implementaci původního záměru na zachování mezinárodního statusu města, Jeruzalém byl ovšem na základě uzavření př́měří v roce $1949^{48}$ de facto rozdělen na západní izraelskou část a východní jordánskou část. ${ }^{49}$ Toto rozdělení plynulo z dohody uzavřené mezi nově vzniklým státem Izrael a Jordánským královstvím. Součástí této dohody bylo vytyčení i hranice príměří, tzv. zelené linie, která byla oběma stranami uznána. Ačkoliv tato demarkační linie nebyla státní hranicí, byla oběma stranami přijata za závaznou. Zelená linie protínala město Jeruzalém, který byl de facto rozdělen na západní část, spravovanou státem Izrael, a východní část, kterou stejně jako území dnešního palestinského Západního břehu spravovalo Jordánsko a považovalo ji za své území. ${ }^{50}$ Ke změně situace došlo v důsledku šestidenní války v roce 1967, kdy započala izraelská okupace tohoto území.

V souvislosti s výsledkem první arabsko-izraelské války se objevila i úvaha o „funkční internacionalizaci Jeruzaléma“", tj. mezinárodního režimu omezeného pouze na svatá místa, která se nacházela $\mathrm{v}$ oblasti okupované jordánskou armádou. ${ }^{51}$ Valné shromáždění přijalo v roce 1949 rezoluci 303 (IV), ${ }^{52}$ na jejímž základě mělo dojít $\mathrm{k}$ přeměně Jeruzaléma v corpus separatum s vlastním guvernérem, zákonodárnou radou, nezávislou soudní mocí a zvláštní policejní složkou. Jeruzalém měl v této podobě podléhat Poručenské radě OSN. Na základě této rezoluce mělo dojít k vytvoření vnějších hranic města, které přetvářely nejen stávající hranice města, ale také zasahovaly do přilehlých arabských vesnic a měst. Plán této rezoluce nebyl príijat Jordánskem ani Izraelem, s výjimkou izraelského souhlasu s mezinárodním režimem ve vztahu ke svatým místům. ${ }^{53}$

V praxi nedocházelo k naplňování plánu internacionalizace Jeruzaléma, na místo toho stát Izrael přikročil k výkonu suverenity vůči západní, moderní části Jeruzaléma

45 QUIGLEY, c. d., s. 14.

46 UNITED NATIONS. Resolution 303 (IV). Palestine: question of an international regime for the Jerusalem area and the protection of the Holy Places [online], 1949 [cit. 23. 12. 2018]. Dostupné na: https://unispal .un.org/DPA/DPR/unispal.nsf/0/2669D6828A262EDB852560E50069738A.

47 CASSESE, c. d., s. 19.

48 Israel-Jordan Armistice Agreement (1949) [online], 3. 4. 1949 [cit. 23. 12. 2018]. Dostupné na: http:// www.jewishvirtuallibrary.org/israel-jordan-armistice-agreement-1949.

49 QUIGLEY, c. d., s. 14.

50 SCOBBIE - HIBBIN, c. d., s. 53-64.

51 CASSESE, c. d., s. 19.

52 UNITED NATIONS. Resolution 303 (IV). Palestine: question of an international regime for the Jerusalem area and the protection of the Holy Places [online], 1949 [cit. 23. 12. 2018]. Dostupné na: https://unispal .un.org/DPA/DPR/unispal.nsf/0/2669D6828A262EDB852560E50069738A.

53 GRIEF, c. d., s. 190. 
a jejího rozšiřování i prostřednictvím zničení přilehlých arabských vesnic Ein Karem, Deir Yassin, Kalonia, El Malha a Lifta, ${ }^{54}$ které nyní jsou součástí Jeruzaléma. Důsledkem tohoto jednání byl do roku 1967 zdvojnásoben počet židovských obyvatel. Vlivem výsledku šestidenní války v roce 1967 vytlačil stát Izrael Jordánsko z daného území a započal výkon vojenské okupační správy části východní části Jeruzaléma vč. svatých míst. ${ }^{55}$ Mezinárodní společenství shledalo jednání státu Izrael v rozporu s oprávněními státu, který vykonává vojenskou okupaci území. Rada bezpečnosti proto rezolucí 446 za tím účelem ustanovila komisi k místnímu šetření v arabských oblastech vč. části Jeruzaléma. Tato komise vydala 12. 7. 1979 zprávu (S/13450), podle které stát Izrael přistoupil k cílenému programu omezení počtu arabských obyvatel Jeruzaléma a naopak zvýšení počtu židovských obyvatel ve městě i v jeho přilehlých oblastech. Podle zprávy této komise jednání státu Izrael může znamenat porušení Čtvrté ženevské úmluvy o ochraně civilních osob za války a souvisejících rezolucí OSN, konkrétně rezoluce Rady bezpečnosti 237 z roku 1967, 252 z roku 1968 a 298 z roku 1971, rezoluce Valného shromáždění 2253 (ES-V) z roku 1967, 2254 (ES-V) z roku 1977 a 33/113 z roku $1978 .{ }^{56}$ Porušení konkrétně spočívalo ve výstavbě nových židovských čtvrtí a osad na okupovaném území, vyvlastňování a konfiskace území a přesunu civilního izraelského obyvatelstva $\mathrm{k}$ trvalému pobytu na okupovaném území. ${ }^{57}$ Mezinárodní humanitární právo obsahuje ustanovení, která umožňují vzít v úvahu vojenskou nezbytnost za určitých okolností. Tato ustanovení se ovšem nevztahují na čl. 49 odst. 6 IV. Ženevské úmluvy, který zakazuje přesun vlastního obyvatelstva na okupované území. Ve vztahu k čl. 53 může být ospravedlněna výjimka ze zákazu ničení osobního majetku v př́padě, kdy jsou tyto operace naprosto nezbytné. MSD ve svém posudku Palestinsko-izraelská zed' z roku 2004 shledal, že není přesvědčen o tom, že ničení v rozporu s čl. 53 byla zcela nezbytná. ${ }^{58}$ Stát Izrael jako okupující mocnost nemá právo zabrat či zkonfiskovat arabské území a na něm následně stavět osady. Jako okupující vojenská mocnost má stát Izrael toliko právo dočasné správy území pro vojenské účely, a tedy nemůže jednat jako územní suverén, anektovat či kolonizovat okupované území. ${ }^{59}$ Podle rezoluce Rady bezpečnosti 465 z 1. 3. 1980 jakékoliv jednání státu Izrael ve vztahu k oblastem Starého města a moderního Jeruzaléma je neplatné ${ }^{60}$ a představuje porušení rezoluce Valného shromáždění 181 (II) a 303 (IV), Čtvrté ženevské úmluvy o ochraně civilních osob za války a tvoří překážku mírového procesu na Blízkém východě, Rada bezpečnosti prostřednictvím této rezoluce vyzvala všechny státy $\mathrm{k}$ tomu, aby neposkytovaly státu Izrael žádnou pomoc v souvislosti s výstavbou a rozšiřrováním osad na okupovaném území. ${ }^{61}$

Veřejné budovy ve vlastnictví státu a území, na němž se tyto nemovitosti nacházejí, si okupující stát nemůže přivlastnit prostřednictvím anexe. Během probíhající vojenské

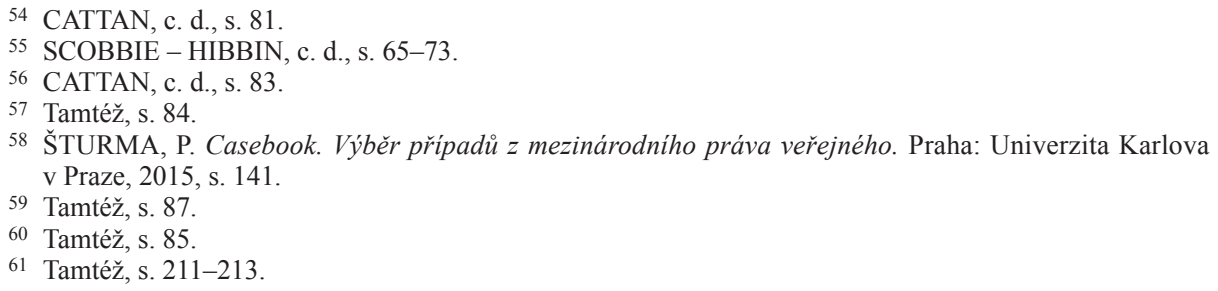


okupace území nepřítele nesmí okupující mocnost nemovitosti prodat, pakliže se to stane, okupující mocnost odcizí území a veřejné budovy neprríteli. Podle čl. 55 haagských úmluv jednání okupující mocnosti může spočívat pouze v podobě správy veřejných budov, nemovitostí, lesů, polností patřících nepřátelskému státu a nacházejících se v okupovaném území. ${ }^{62}$

Jak Rada bezpečnosti v textu rezoluce 252 z roku 1968, 267 z roku 1969, tak i Valné shromáždění v textu rezoluce 2253 z roku 1967 odsoudily jednostranné opatření v podobě tzv. de facto anexe. ${ }^{63}$ Rezoluce Rady bezpečnosti $252^{64}$ označila všechna legislativní a administrativní opatření a jednání státu Izrael vč. vyvlastnění území a soukromého vlastnictví, které směřovalo ke změně právního statusu Jeruzaléma, jako neplatné a je nemožné, aby na základě takového jednání došlo ke změně právního statusu. Rezoluce 252 dále požadovala anulování všech opatření, k nimž Izrael přistoupil, a k bezodkladnému ukončení veškerého budoucího jednání směřujícího ke změně statusu Jeruzaléma. Rezoluce 267 odsoudila v nejsilnějším úhlu pohledu veškeré jednání učiněné ke změně statusu města Jeruzaléma ${ }^{65}$ a potvrdila, že jakékoliv izraelské administrativní a legislativní jednání ke změně statusu Jeruzaléma vč. vyvlastnění území a soukromého majetku je neplatné, a tudíž nemůže vést ke změně statusu a apelovala na stát Izrael, aby se do budoucna takového jednání zdržel.

Izrael nejednal v souladu s ustanovením výše uvedených rezolucí, naopak přijal již v roce 1967 vnitrostátní právní předpis, podle něhož byl Jeruzalém jako celek začleněn do městské a administrativní sféry tamní vlády. ${ }^{66}$ Administrativní včlenění Jeruzaléma do území Izraele bylo v následujících letech dále podpořeno několika judikáty izraelských soudů a konečně byl dne 30. 6. 1980 přijat „,základní zákon“, který lze považovat za jistou obdobu ústavního zákona, podle něhož byl celý Jeruzalém učiněn integrální součástí státu Izrael a stal se jeho hlavním městem. ${ }^{67} \mathrm{Na}$ to reagovala Rada bezpečnosti rezolucí 478 a shledala jednání izraelského parlamentu za neplatné, nicotné a porušující pravidla mezinárodního práva. ${ }^{68}$ Právní účinky tohoto jednostranného vnitrostátního aktu byly mezinárodním společenstvím shledány jako neplatné z důvodu porušení zákazu nabytí územního zisku s použitím síly a zároveň i jednání v podobě připojení části okupovaného území k území okupujícího státu, které je v rozporu s ustanovením mezinárodního humanitárního práva, konkrétně Čtvrté ženevské úmluvy o ochraně civilních obyvatel.

V roce 1988 se Jordánsko definitivně vzdalo nároku na území Západního břehu vč. Východního Jeruzaléma a Palestinská národní samospráva poté vyhlásila vznik státu

62 OPPENHEIM, L. - LAUTERPACHT, H. International Law: A Treatise. Vol. 2: Disputes, War and Neutrality. London: Longman, 1952, s. 397.

63 QUIGLEY, c. d., s. 17.

64 UNITED NATIONS. Security Council, Resolution 252 [online], 1968 [cit. 23. 12. 2018]. Dostupné na: http://unscr.com/en/resolutions/252.

65 UNITED NATIONS. Security Council, Resolution 267 [online], 1969 [cit. 23. 12. 2018]. Dostupné na: http://unscr.com/en/resolutions/267.

66 Srov. QUIGLEY, c. d., s. 15.

67 CASSESE, c. d., s. 28, QUIGLEY, c. d., s. 18.

68 UNITED NATIONS. Security council, Resolution 478 [online], 1980 [cit. 23. 12. 2018]. Dostupné na: http://unscr.com/en/resolutions/478. UNITED NATIONS. Security Council, Resolution 476 [online], 1980 [cit. 23. 12. 2018]. Dostupné na: http://unscr.com/en/resolutions/476. 
Palestina na svém palestinském území s hlavním městem Jeruzalémem, přičemž územím státu Palestina bylo jak pásmo Gazy, tak Západního břehu a hlavním městem se rozuměl toliko Východní Jeruzalém. V roce 2000 probíhala v Camp Davidu první jednání mezi prredstaviteli státu Izrael a Palestinci, která se týkala otázek souvisejících s možností vzniku palestinské suverenity vůči části Jeruzaléma. Obě strany se shodly, že plán rezoluce 181 (II) na internacionalizaci pro tyto zúčastněné strany již není relevantní. Tato jednání ovšem byla bez výsledku ukončena v důsledku odmítavého postoje představitelů palestinské delegace. Bylo zřejmé, že původní záměr rezoluce 181 (II) „vyprchal“, a naopak z pozdější úpravy vyplývalo, že Jeruzalém bude rozdělen mezi státy Izrael a Palestina. O rozdělení Jeruzaléma strany jednaly i o rok později, v roce 2001, v egyptské Tabě, $\mathrm{k}$ dosažení dohody ovšem nedošlo.

V roce 2012 bylo na půdě Valného shromáždění odhlasováno uznání státu Palestina ${ }^{69} \mathrm{~s}$ hlavním městem Východním Jeruzalémem a hranicemi před událostmi šestidenní války v roce 1967 jako nečlenského státu OSN s pozorovatelským statusem. Stalo se tak prostřednictvím rezoluce Valného shromáždění $67 / 19 .{ }^{70} \mathrm{~K}$ tomuto uznání došlo šedesát pět let poté, co byla stejným orgánem přijata rezoluce 181 (II), podle níž měl mít Jeruzalém status corpus separatum. Kromě 193 členských států71 vystupuje na půdě OSN mnoho nositelů statusu pozorovatele, mezi něž řadíme mezinárodní organizace, různé státní i nestátní entity. Pozorovatelé mají právo mluvit na většině zasedání Valného shromáždění Organizace spojených národů, mají volný př́istup k dokumentům, dále mají právo účastnit se procedurálního hlasovaní a zároveň i podporovat a podepisovat rezoluce, nemají však právo hlasovat o rezolucích a dalších podstatných usneseních. ${ }^{72}$ Status pozorovatele je udělován rezolucí Valného shromáždění Organizace spojených národů. V roce 2018 bylo zároveň přijato rozhodnutí na půdě Valného shromáždění, že v průběhu roku 2019 bude Palestina moci vystupovat více jako členský stát z důvodu výkonu funkce předsednictví skupiny 77 rozvojových států. ${ }^{73}$

Uznání státu Palestina nečlenským státem v OSN předcházelo již v roce 1974 uznání Organizace pro osvobození Palestiny (dále jen OOP) jako zástupce nestátní entity, která měla možnost vystupovat na půdě Valného shromáždění. Dalším krokem bylo v roce 1988 uznání vyhlášení státu Palestina. Stalo se tak prostřednictvím rezoluce Valného shromáždění 43/177. Uznání státnosti Palestiny dále zahrnovalo uznání teritoriální suverenity státu Palestina vůči území okupovanému státem Izrael od roku $1967 .{ }^{74}$ Krátce

69 Pro hlasovalo 138 států, proti hlasovalo 9 států a 41 států se zdrželo hlasování, v rámci Evropské unie jako jediná hlasovala Česká republika proti uznání.

70 UNITED NATIONS. General Assembly Resolution 67/19 Status of Palestine in the United Nations [online], 2012 [cit. 23. 12. 2018]. Dostupné na: https://unispal.un.org/DPA/DPR/unispal.nsf/0/19862D03 C564FA2C85257ACB004EE69B.

71 About U. N. Membership. In: United Nations [online], 2018 [cit. 23. 2. 2019]. Dostupné na: https://www .un.org/en/sections/member-states/about-un-membership/index.html.

72 About Permanent Observers. In: United Nations [online], 2018 [cit. 23. 2. 2019]. Dostupné na: https:// www.un.org/en/sections/member-states/about-permanent-observers/index.html.

73 Pro hlasovalo 146 států, proti hlasovaly 2 státy, USA a Izrael, 29 států se hlasování nezúčastnilo a 15 států nebylo hlasování př́tomno. NICHOLS, M. U. N. Allows Palestinians to act more like a full member in 2019. In: Reuters [online], 2018 [cit. 23. 2. 2019]. Dostupné na: https://www.reuters.com/article/us -palestinians-un/un-allows-palestinians-to-act-more-like-full-member-in-2019-idUSKCN1MQ2R7.

74 UNITED NATIONS. General assembly. Resolution 43/177 [online], 1988 [cit. 23. 2. 2019]. Dostupné na: https://www.un.org/documents/ga/res/43/a43r177.htm. 
po vyhlášení této rezoluce došlo k výslovnému uznání státnosti Palestiny přibližně stovkou členských států OSN. V roce 1993 v rámci mírového jednání v Oslu došlo k podpisu dokumentu Deklarace o zásadách palestinské autonomie v Oslu, ${ }^{75}$ jíž předcházelo vzájemné uznání zúčastněných stran konfliktu, státu Izrael a OOP. K uznání došlo prostřednictvím výměny korespondence mezi izraelským předsedou vlády Yitzchakem Rabinem a předsedou OOP Jásirem Arafatem. ${ }^{76}$ Stát Izrael vyjádřil uznání OOP jakožto organizace reprezentující zájmy palestinského lidu a strany, s níž je ochoten vyjednávat o mírovém řešení konfliktu. Do dnešního dne stát Izrael nevyjádřil uznání státu Palestina. Za tacitní uznání státu nelze považovat např. členství v mezinárodních organizacích či uzavření nebo přistoupení $\mathrm{k}$ vícestranné mezinárodní smlouvě. Stát Izrael vystupuje na půdě OSN jako členský stát, tato skutečnost nemůže zakládat akt jeho uznání arabskými státy, které jsou také členy této univerzální mezinárodní organizace. ${ }^{77}$ Ačkoliv z pohledu mezinárodního práva lze Palestinu považovat spíše za stát, byt' některé aspekty spojené především s výlučným výkonem suverenity vůči svému území bez vnějšího zásahu jiného státu naplněny nejsou, stát Izrael i nadále vede jednání výhradně s představiteli OOP, nikoliv s predstaviteli státu Palestina. ${ }^{78}$ Stát Palestina je nositelem statusu nečlenského státu v mezinárodní organizaci univerzálního charakteru, v OSN, naopak ale má členství v několika organizacích partikulární povahy, např. v UNESCO. Palestinské členství v UNESCO bylo navrženo již v roce 1989 a v roce 2011 byla Palestina přijata za člena této organizace. ${ }^{79} \mathrm{~V}$ reakci na členství Palestiny v UNESCO přestaly USA a Izrael platit členské př́spěvky ${ }^{80}$ a dle platných stanov této organizace pozbyly hlasovací právo. ${ }^{81}$

\section{NÁZORY NAUKY O DE FACTO ROZDĚLENÍ JERUZALÉMA}

Ačkoliv se plán internacionalizace Jeruzaléma od roku 1952 jevil opuštěným ve smyslu jeho realizace, byla na půdě OSN přijata řada rezolucí, jak rezolucí Valného shromáždění majících doporučující, právně nezávaznou povahu, tak rezolucí právně závazných vytvořených Radou bezpečnosti. Řečené rezoluce měly vesměs negativní charakter, a sice ukládaly státu Izrael, aby ukončil jednání ve smyslu změny statusu okupované části Jeruzaléma a zdržel se jednání, které by mělo účinky anexe tohoto území.

75 Declaration of Principles (Oslo I, 1993). In: The Israeli Palestinian Conflict, An Interactive Database (beta) [online]. Tel Aviv, 2015, s. 178-180 [cit. 28. 4. 2019]. Dostupné na: https://ecf.org.il/issues/issue $/ 184$.

76 Exchange of letters of Israel-PLO mutual recognition (1993). In: The Israeli Palestinian Conflict, An Interactive Database (beta) [online]. Tel Aviv, 2015 [cit. 28. 4. 2019], s. 178-180. Dostupné na: https://ecf .org.il/issues/issue/15.

77 ONDŘEJ, J. - MRÁZEK, J. - KUNZ, O. Základy mezinárodního práva veřejného. Praha: C. H. Beck, 2018, s. 81. ČEPELKA - S̆TURMA, c. d., s. 53.

78 MRÁZEK, J. Právní postavení Palestiny a otázka jejího uznání jako státu. Právník, 2012, roč. 151, č. 8, S. $855-860,863$.

79 Pro hlasovalo 107 států, proti hlasovalo 14 států, 52 států se zdrželo a 12 států se hlasování neúčastnilo.

80 UNESCO tím ztratilo přibližně čtvrtinu př́ijmů.

81 MRÁZEK, J. Právní postavení Palestiny a otázka jejího uznání jako státu. Právník, 2012, roč. 151, č. 8, s. 869. 
Ve vztahu k řešení právních otázek souvisejících s rozdělením či internacionalizací Jeruzaléma a př́padnému budoucímu uzavréení mezinárodní dohody je nutná podpora OSN. Charakteru vystupování státu Izrael odpovídá jednání mající rysy popírání autority OSN. Odmítání autority OSN státem Izrael ovšem nevytváří žádné účinky mezinárodního obyčeje, díky nimž by stát Izrael mohl nabýt platnou teritoriální suverenitu vůči Jeruzalému. ${ }^{82}$ OSN by nikdy ani hypoteticky nemohlo zvažovat schválení anexe Východního Jeruzaléma okupujícím státem Izrael, takové schválení by bylo i mimo jiné v př́mém rozporu s rezolucí 242 Rady bezpečnosti, která nepřipouští možnost nabytí území na základě války, uvádí povinnost státu Izrael ukončit vojenskou okupaci a konečně všem aktérům šestidenní války ukládá povinnost vzájemně respektovat územní suverenitu a její celistvost, politickou nezávislost, právo na život v míru v rámci vytyčených hranic a zakazuje použít sílu či hrozbu silou proti jinému státu. ${ }^{83}$

OSN nikdy nenavrhlo konečnou podobu řešení otázky Jeruzaléma, jinými slovy netrvalo striktně na jeho internacionalizaci, a ani nepodpořilo rozdělení Jeruzaléma na dvě části mezi stát Izrael a Palestina. ${ }^{84} \mathrm{Na}$ místo toho OSN upřednostnila ponechání řešení těchto otázek otevřené, OSN se odmítla přiklonit ke konkrétní variantě řešení sporu o suverenitu vůči historické části Starého města. OSN projevila zájem na zachování plné kompetence ke svému disponování s územím, ponechala si tedy práva ke schválení a odsouhlasení jakékoliv právní změny statusu Jeruzaléma. ${ }^{85}$

V nauce lze nalézt protichůdné názory, které rozporují jak postoj Rady bezpečnosti, tak posudek Mezinárodního soudního dvora ve věci zdi oddělující okupované palestinské území od státu Izrael. ${ }^{86}$ Mezi ně lze zařadit např. Bluma, Lauterpachta, Goldberga a Schwebela, kteří předkládají odůvodnění právního nároku na teritoriální suverenitu státu Izrael vůči Jeruzalému jako celku. Autorka níže uvádí velmi stručně stěžejní body argumentace těchto autorů.

Podle Schwebela je rozšíření izraelské suverenity na Východní Jeruzalém v souladu $\mathrm{s}$ mezinárodním právem, a to $\mathrm{z}$ důvodu, že ,state acting in the lawful exercise of self defense, may seize and occupy foreign territory as long as such seizure and occupation are necessary to its self-defense ", 87 dle Schwebela je jednání státu Izrael v souladu s právem z toho důvodu, že pro účel výkonu sebeobrany je nezbytné přistoupit ke zkonfiskování a jeho okupaci, a dále z důvodu, že ,the prior holder of the territory (Jordan) had unlawfully seized the territory ... so the state (Israel) has against the prior holder better (or stronger) title“. ${ }^{88}$

82 Tamtéž.

83 UNITED NATIONS. Security Council. Resolution 242 [online], 1967 [cit. 23 .12. 2018]. Dostupné na: http://unscr.com/en/resolutions/242. SCOBBIE - HIBBIN, c. d., s. 74-84.

84 CATTAN, c. d., s. 117.

85 CASSESE, c. d., s. 34.

86 Legal Consequences of the Construction of the Wall in the Occupied Palestinian Territory. Advisory Opinion, I. J. C. Reports 2004, s. 136.

87 SCHWEBEL, S. Justice in International Law. Selected Writings of Judge Stephen M. Schwebel. Cambridge: Cambridge University Press, 1994, s. 521-529.

88 Tamtéž. 
Blum posuzuje relativní nárok na území a uvádí, že „no state can make a claim to ... Jerusalem that is equal to of Israel, ... (which has) relatively superior claim ... (which is) indistinguishable from ... a valid title holder". 89

Podle Lauterpachta ,terrirorial change as a result of the unlawful use of force is impermissible“ ${ }^{90}$ jestliže bylo území v minulosti v držení subjektu, který jej získal protiprávním použitím síly, je tedy možné ,use the force to restore the lawful sovereign“.91

Dle Goldberga se rezoluce 242 týká toliko otázek východní části Jeruzaléma, která je okupovaným územím, přičemž jeho status ,should be negotiable ... and the armistice lines (Green Line from 1949) dividing Jerusalem were no longer viable“" 92 z čehož lze odvodit, že dle názoru Goldberga Zelená linie není právně závaznou hranicí mezi státy Izrael a Palestina.

Baron v návaznosti na výše uvedené názory a současně se zohledněním skutečnosti, že „East Jerusalem ... had no independent existence in fact prior to Jordan's invasion of the City in 1948“93 vyvozuje, že stát Izrael může aplikovat princip výkonu práva na sebeurčení vůči celému městu, faktické rozdělení na západní a východní část mělo toliko povahu vymezení linie mezi státem Izrael a Jordánskem pro účel uzavření prríměří, Baron tak přejímá Goldbergův názor.

Dle názoru autorky jsou výše uvedené prríklady značně kontroverzní a jistě by vyžadovaly detailnější rozbor a kritickou analýzu.

Valné shromáždění OSN je oprávněno (stejně jako Rada bezpečnosti) požádat Mezinárodní soudní dvůr o posudky ke kterékoliv právní otázce. V prrípadě posudku Mezinárodního soudního dvora týkajícího se Palestinsko-izraelské zdi z roku 2004 došlo k jeho vypracování na žádost Valného shromáždění OSN obsaženou v rezoluci ES-10/14,94 přijaté na jeho desátém naléhavém zvláštním zasedání v roce 2003.

Autoři Čepelka a Šturma se zabývají otázkou právní závaznosti posudků MSD a uvádějí, že ,posudky MSD jsou právně nezávazné, mohou mít však velkou váhu morální a ... Valné shromážděni i Rada bezpečnosti a dalši orgány OSN a organizace o posudek o kterékoliv právni otázce souvisejicí s jejich činností požádají na základě zmocnění Valným shromážděním dle čl. 96 Charty a čl. 65 Statutu MSD. Dle názorů nauky jsou ty to posudky právně nezávazné a orgány a organizace, které o tyto posudky požádaly, se jimi v praxi fakticky většinou také rídi '“95 Otázky obsažené v žádosti o posudek se MSD předkládají písemnou žádostí přesně vymezující otázku, o kterou jde, a doloží všechny doklady, které mohou otázku objasnit.

V tomto konkrétním případě byla formulována otázka následovně: „Jaké jsou právní následky vyplývajicí z výstavby zdi, která je budovaná Izraelem, okupační mocností, na

89 BLUM, Y. Z. The Juridical Status of Jerusalem. Jerusalem: Hebrew University of Jerusalem. Leonard Davis Institute for International Relations, 1974, s. 15-24. Srov. SCOBBIE - HIBBIN, c. d., 89-92.

90 LAUTERPACHT, E. Jerusalem and the Holy Places. London: Anglo - Israel Association, 1968, s. 44.

91 Tamtéž.

92 GOLDBERG, A. J. What Resolution 242 Really Said. In: American Foreign Policy Interests, The Journal of the National Committee on American Foreign Policy, Vol. 33, No. 1, s. 41-46.

93 BARON, c. d., s. 9.

94 UNITED NATIONS. General Assembly Resolution ES-10/14 Illegal Israeli actions in Occupied East Jerusalem and the rest of the Occupied Palestinian Territory [online], 2003 [cit. 14. 5. 2019]. Dostupné na: https://unispal.un.org/DPA/DPR/unispal.nsf/0/F953B744269B9B7485256E1500776DCA.

95 ČEPELKA - ك̌STURMA, c. d., s. 566. 
Okupovaném palestinském území, včetně v rámci a okolo Východniho Jeruzaléma, jak je popsána ve zprávě generálního tajemnika, s přihlédnutím k pravidlìm a zásadám mezinárodniho práva, včetně IV. Ženevské úmluvy z roku 1949 a přislušných rezolucí Rady bezpečnosti a Valného shromážděni?"

Valné shromáždění vyžádalo uvedený posudek v otázce, která se kryje s nevyřešeným sporem mezi státy Izrael a Palestina a z toho důvodu se MSD řídí procesními předpisy pro řízení o věcech sporných (which apply in contentious cases, čl. 68 Statutu $\mathrm{MSD}^{97}$ ) v rozsahu, $\mathrm{v}$ jakém je pokládá za použitelné.

MSD shledal, že Valné shromáždění bylo oprávněno v této konkrétní věci o posudek žádat, a sice dle čl. 96 odst. 1 Charty, protože jde o otázku spadající do kompetence VS dle čl. 10 a 11 Charty, a dále shledal, že VS nepřekročilo své oprávnění (čl. 12 Charty). Soud shledal, že VS požádalo o posudek v situaci, kdy Rada bezpečnosti, jakožto orgán, jehož primární zodpovědnost je udržování mezinárodního míru a bezpečnosti, nebyla schopná přijmout (svou povahou právně závaznou) rezoluci o výstavbě této zdi, a sice $\mathrm{v}$ důsledku veta stálého člena. MSD odmítl názor, že by se $\mathrm{v}$ tomto konkrétním prŕpadě neměl otázkou zabývat, protože nejde o otázku právní, ale spíše politické povahy. MSD uvedl, že nesouhlas státu s jurisdikcí se nevztahuje na posudkovou činnost soudu a že vytvoření posudku $\mathrm{v}$ tomto konkrétním př́ípadě nemá účinky obcházení principu souhlasu státu s jurisdikcí soudu z důvodu, že předmět předložené otázky se nachází v mnohem širší rovině, než jen dvoustranný spor mezi státy Izrael a Palestina a je v přímém zájmu OSN. MSD nepřijal tvrzení, že by měl odmítnout vytvořit žádaný posudek $z$ důvodu, že jeho názor by mohl být překážkou politických jednání o řešení sporu mezi aktéry konfliktu. ${ }^{98}$

Dle autorů Čepelky a Šturmy se v jednotlivých př́ípadech požaduje souhlas zainteresovaných států s jurisdikcí MSD, nebot' jde v obecné rovině o tzv. posudky s funkcí rozsudku ${ }^{99}$ Autoři Čepelka a Šturma uvádějí v konkrétním př́padě poradního posudku vǔči státu Izrael ${ }^{100}$ slovní spojení ,odsuzující posudek“, z důvodu, že MSD vyložil výstavbu zdi jako porušení mezinárodního práva (described the construction of the wall as a violation of international law ${ }^{101}$ ). MSD $\mathrm{k}$ vypracování posudku přes absenci souhlasu státu Izrael přistoupil také proto, že část této zdi je vybudována na území, které je okupovaným územím, na němž zároveň dochází v rozporu s režimem vojenské okupace dle platného mezinárodního humanitárního práva k výstavbě osad pro izraelské civilisty. To představuje závažné (hrubé) porušení čl. 49 Čtvrté ženevské úmluvy o ochraně civilních osob za války, který stanoví zákaz přesunu vlastního civilního obyvatelstva na okupované území. ${ }^{102}$

\footnotetext{
96 ŠTURMA, P., c. d., s. 136.

${ }^{97}$ ONDŘEJ, J. - POTOČNÝ, M. Obecné mezinárodní právo v dokumentech. Praha: C. H. Beck, 2000, s. 244.

98 ICJ. Legal Consequences of the Construction of the Wall in the Occupied Palestinian Territory. Overview of the case [online], 2004 [cit. 14. 5. 2019]. Dostupné na: https://www.icj-cij.org/en/case/131.

99 ČEPELKA - ŠTURMA, c. d., s. 566.

${ }^{100}$ Legal Consequences of the Construction of the Wall in the Occupied Palestinian Territory. Advisory Opinion, I. J. C. Reports 2004, s. 136.

101 ČEPELKA - ŠTURMA, c. d., s. 567.

${ }^{102}$ Geneva Convention of 12 August 1949 on the Protection of Civilian Persons in Time of War, UNTS, vol. 75 , No. 973, Art. 49(6).
} 
Dle platného mezinárodního práva tedy nelze uznat izraelskou anexi Východního Jeruzaléma a uplatňování územní suverenity státu Izrael vůči němu. Po šestidenní válce vykonává stát Izrael vojenskou okupaci, a tudíž je jeho činnost podřizena režimu Čtvrté ženevské úmluvy o ochraně obětí ozbrojených konfliktů. V souladu s ní vojenská okupační síla nemůže nabýt suverenitu k území, které je předmětem okupace, ani v př́ípadě, že jiný stát vůči tomuto území v minulosti vykonával kontrolu, či v situaci, že je síly znovu použito za účelem odražení protiprávního útoku. ${ }^{103}$ Dle názoru autorky vedle skutečnosti porušení Čtvrté ženevské úmluvy nemůže obstát výše zmíněná argumentace Schwebela, Bluma, Lauterpachta, Goldberga a Barona. I v případě, že by hypoteticky Jordánsko nebylo držitelem území Západního břehu v souladu s právem (což je samo o sobě samostatnou otázkou, na kterou je problematické ve stručnosti odpovědět $\mathrm{z}$ důvodu existence protichůdných právních pramenů a v neposlední řadě i celé řady názorů nauky) a stát Izrael by dle jejich názorů s použitím vojenské síly znovu právoplatně nabyl dané území, jednání státu Izrael v tomto př́padě představuje hrubé porušení kogentních norem mezinárodního práva a zájem na jejich dodržování je z právního hlediska nesporný a dle názoru autorky převažující uvedené argumenty.

Anexe Východního Jeruzaléma je porušením čl. 47 Čtvrté ženevské úmluvy. ${ }^{104}$ Jednání státu Izrael v podobě budování sídlišt’ a výstavby bytových komplexů ve Východním Jeruzalému za účelem usídlování židovských obyvatel na tomto území je v př́mém rozporu s oprávněními okupující mocnosti 105 dle čl. 49 odst. 6 .

V souvislosti s de facto rozdělením Jeruzaléma po první arabsko-izraelské válce odůvodnil stát Izrael svůj nárok na západní část Jeruzaléma vniknutím Jordánska do města Jeruzaléma a na území bývalého mandátu Palestina, které představovalo porušení ${ }^{106}$ čl. 2 odst. 4 Charty. ${ }^{107}$ Jednání Izraele bylo vysvětleno na základě výkonu práva na sebeobranu dle čl. 51 Charty. ${ }^{108}$

Cassese naopak posuzuje de facto rozdělení Jeruzaléma a nabytí suverenity vůči jeho částem $\mathrm{s}$ ohledem na výsledky ozbrojeného konfliktu v obecné rovině (bez prímé souvislosti s událostmi první arabsko-izraelské války, jejíž výsledek umožnil státu Izrael započít správu západní části Jeruzaléma, či událostmi šestidenní války, po jejímž konci stát Izrael získal př́stup i ke zbývajícím částem Jeruzaléma, kromě historické části Starého města i k dnešnímu palestinskému Východnímu Jeruzalému). Uvádí, že stát může nabýt suverenitu vůči určitému území pouze za striktního kumulativního naplnění několika následujících podmínek. Podle první podmínky před tím, než dojde k použití

${ }^{103}$ Obecně k př́tomnosti státu na určitém území v režimu okupace následující po vojenské porážce státu, jehož dřívější př́tomnost na témže území nebyla v souladu s platným právem. OPPENHEIM, L. - LAUTERPACHT, H. International law: A treatise. Vol. 1, Peace. Philadelphia: David McKay, 1955, s. 545.

${ }^{104}$ Convention (IV) respecting the Laws and Customs of War on Land and its annex: Regulations concerning the Laws and Customs of War on Land. Hague [online], 1907 [cit. 23. 12. 2018]. Dostupné na: https:// ihl-databases.icrc.org/ihl/INTRO/195?OpenDocument.

105 QUIGLEY, c. d., s. 22.

${ }^{106}$ CASSESE, c. d., s. 23. Srov. QUIGLEY, c. d., s. 16, vykládá čl. 51 Charty jako akt kolektivní sebeobrany Jordánska vůči agresorovi, státu Izrael; čl. 2 odst. 4 Charty vykládá ve smyslu povinnosti vrácení území nabytého prostřednictvím použití síly a vojenské agrese pưvodnímu suverénovi.

${ }^{107}$ Charta Organizace spojených národů a Statut mezinárodního soudního dvora [online], 1945 [cit. 23. 12. 2018]. Dostupné na: http://www.osn.cz/wp-content/uploads/2015/03/charta-organizace-spojenych -narodu-a-statut-mezinarodniho-soudniho-dvora.pdf.

108 Srov. BARON, c. d., s. 6. 
síly, nesmí být pochyb o tom, že územní suverenita náleží stejnému státu, který sílu použil za účelem vytlačení protiprávního okupanta. Podle druhé podmínky musí stát vyčerpat všechny možné prostředky mírového uspořádání sporu o dané území a především se musí obrátit s žádostí o pomoc na Radu bezpečnosti. Pakliže Rada bezpečnosti nepřistoupí k opatřením směřujícím k ukončení protiprávní okupace území, teprve poté může dle Casseseho stát použít vlastní ozbrojené síly. Podle třetí podmínky použití síly nesmí přesáhnout hranici omezenou cílem znovunabytí území. Cassese uvádí, že stát Izrael nebyl územním suverénem před invazí jordánského vojska, a tudíž nemohl (znovu)nabýt titul územní suverenity za použití vojenské síly. ${ }^{109}$

V roce 1950 vyhlásil Izrael ve svém základním zákoně Západní Jeruzalém svým hlavním městem, ani Valné shromáždění ani Rada bezpečnosti nepřijaly žádnou rezoluci požadující ukončení provádění změn statusu Jeruzaléma. Ke změně došlo až v roce $1967,{ }^{110}$ kdy po událostech šestidenní války začal stát Izrael rozšiřovat své nároky i na území Východního Jeruzaléma. V reakci na to Valné shromáždění v rezoluci 2253 požadovalo, aby Izrael zrušil všechna opatření směřující ke změně statusu Jeruzaléma. ${ }^{111}$ Dva státy, El Salvador a Costa Rica, uznaly Západní Jeruzalém jako hlavní město Izraele i tím, že umístily svá velvyslanectví právě na území západní části Jeruzaléma. Absence protestu mezinárodního společenství při nabytí územního titulu státu Izrael k Západnímu Jeruzalému ovšem neznamená souhlas mezinárodního společenství projevený mlčky. Mezinárodní společenství toliko vyjádřilo souhlas s výkonem správy Jeruzaléma prostřednictvím Izraele a Jordánska. Nabytí právního nároku na území a výkon územní suverenity vůči dotčenému území nemůže vzniknout na základě absence protestu mezinárodního společenství. Izrael a Jordánsko nenabyly de jure suverenitu vưči př́íslušným částem Jeruzaléma, naopak Izrael a Jordánsko získaly uznání de facto okupujících států ve vztahu k území Jeruzaléma. ${ }^{112}$

Město Jeruzalém bylo také předmětem jednání mezi státem Izrael a Organizací pro osvobození Palestiny, která probíhala v devadesátých letech minulého století v Oslu, v roce 2000 v americkém Camp Davidu a v roce 2001 v egyptské Tabě. Do současné doby nedošlo $\mathrm{k}$ vyřešení otázek souvisejících s Jeruzalémem ani k jeho případnému rozdělení. Vytvoření konsensu ohledně suverenity vưči Jeruzalému či jeho částem, tedy Východnímu Jeruzalému, Západnímu Jeruzalému a Starému městu, může být předmětem př́ípadných budoucích jednání. Organizace spojených národů opakovaně apeluje na stát Izrael, aby upustil od jednání, které by směřovalo k nabytí právního titulu113 vůči Jeruzalému jako celku, a prohlašuje, že jakékoliv protiprávní jednání státu Izrael v tomto smyslu považuje za neplatné.

Stát Izrael v praxi zastává vůči Jeruzalému řadu významných funkcí z důvodu každodenní nutnosti zajistit bezpečnost svých občanů, ochrany bezpečnosti turistů a cizích státních příslušníků s přechodným či trvalým pobytem na území Izraele. Stát Izrael má v neposlední řadě i významnou funkci v oblasti administrativní a správní činnosti

\footnotetext{
${ }^{109}$ CASESSE, c. d., s. 24-25.

110 Srov. HALL, E. International Law. Oxford: Clarendon Press, 1980, s. 143-144.

111 UNITED NATONS Resolution 2253 (ES - V). Measures taken by Israel to change the status of the city of Jerusalem [online], 1967 [cit. 23. 12. 2018]. Dostupné na: http://unscr.com/en/resolutions/2253.

112 CASSESE, c. d., s. 26.

113 BROWNLIE, I. Principles of Public International Law. New York: Oxford University Press, 2003 , s. 164.
} 
a v oblasti budování infrastruktury. Tato činnost je pro místní obyvatele a návštěvníky tohoto města nezbytná, ovšem zároveň představuje i jednání v rozporu s požadavky mezinárodního společenství, zejména co se týká oblasti výstavby bytových komplexů a sídlišt jak na území Východního Jeruzaléma, tak i výstavby a rozšiřování príilehlých osad na území Západního břehu. ${ }^{114}$

Pakliže by stát Izrael, stejně jako stát Palestina zahájily určitou spolupráci s Valným shromážděním a Radou bezpečnosti ve smyslu jednání o určení a konkrétního vytyčení kompetencí vůči Jeruzalému, bylo by případně i možné uvést současný stav do souladu s mezinárodním právem a eventuálně i částečně naplnit původní cíl rezoluce 181 (II) např. v podobě vytvoření mezinárodní správy pro určitou oblast Jeruzaléma, např. pro historické centrum Starého města či pro svatá místa.

\section{6. ÚVAHY O DE JURE ROZDĚLENÍ JERUZALÉMA A SOUČASNÉM PRÁVNÍM A POLITICKÉM VÝVOJI}

V průběhu roku 2018 se několik států přihlásilo $\mathrm{k}$ plánu přesunout své zastupitelské úrady z Tel Avivu do Jeruzaléma. Iniciátorem byly Spojené státy americké na konci roku 2017. K prohlášením se připojila Austrálie, Brazílie a v neposlední řadě i Česká republika, naopak Paraguay se vyjádřila ve smyslu přestěhování velvyslanectví z Jeruzaléma do Tel Avivu.

Mezinárodní právo neupravuje umístění zastupitelských úřadů. Dle obvyklých zvyklostí se ovšem zastupitelské úřady nacházejí v hlavním městě státu. Samotné přestěhování zastupitelského úřadu $\mathrm{v}$ obecné rovině nezakládá akt uznání daného města hlavním městem státu. Bílková poukazuje na odůvodnění přesunu velvyslanectví Spojených států amerických (z Tel Avivu do Západního Jeruzaléma) aktem výslovného uznání Jeruzaléma jako jednotného celku hlavním městem státu Izrael a podotýká, že akt přestěhování zastupitelského úřadu a akt uznání hlavního města nelze s ohledem na prohlášení prezidenta Trumpa od sebe oddělovat $\mathrm{z}$ důvodu, že první akt je potvrzením druhého. Bílková dále uvádí, že uznání Jeruzaléma hlavním městem státu Izrael (nejen Spojenými státy americkými, ale př́padně v budoucnu i dalšími státy) v souladu s mezinárodním právem je možné jen se současným uznáním Jeruzaléma hlavním městem státu Palestina. ${ }^{115}$

S ohledem na předchozí akt uznání státu Palestina s hlavním městem Východním Jeruzalémem a s ohledem na jednání státu Izrael v rozporu s řadou rezolucí Valného shromáždění i Rady bezpečnosti přikazujících ukončení všech aktivit směřujících ke změně statusu Východního Jeruzaléma by byl akt výslovného uznání Jeruzaléma jako celku hlavním městem státu Izrael v rozporu s mezinárodním právem. Do Východního

\footnotetext{
${ }^{114}$ NAPOLITANO, P. Jerusalem: heart of the Israeli-Palestinian conflict. In: European Parliament, Directorate-General for External Policies of the Union. Brussels: Policy Department DG External Policies [online], 2012 [cit. 23. 12. 2018]. Dostupné na: http://www.europarl.europa.eu/RegData/etudes/briefing_note /join/2012/491443/EXPO-AFET_SP(2012)491443_EN.pdf.

${ }^{115}$ BÍLKOVÁ, V. Přesun české ambasády do Jeruzaléma by nemusel znamenat porušení mezinárodních závazků. Novinky.cz [online], 2018 [cit. 23. 12. 2018]. Dostupné na: https://www.novinky.cz/domaci /468791-presun-ceske-ambasady-do-jeruzalema-by-nemusel-znamenat-poruseni-zavazku.html.
} 
Jeruzaléma $\mathrm{v}$ rozsahu hranic před šestidenní válkou $\mathrm{v}$ roce 1967 ovšem spadá i historické centrum Starého města vč. svatých míst zahrnujících krom ostatních místo zvané Západní zed’ či Zed' nářků a Chrámová hora, na níž se nachází Skalní dóm a mešita al-Aksá.

Možnou př́činu dosud nerealizovaného „de jure rozdělení Jeruzaléma“ lze shledat právě v protichůdných postojích obou aktérů. Stát Izrael odmítá pozici okupující vojenské mocnosti vůči Východnímu Jeruzalému, kterou zastává dle mezinárodního společenství, a v neposlední řadě i Mezinárodního soudního dvora, jak bylo uvedeno v poradním posudku týkajícím se problému výstavby zdi kolem okupovaného území Západního břehu. ${ }^{116}$ Stát Izrael nadále vyvíjí aktivity, které by podle mezinárodního práva byl oprávněn vykonávat územní suverén. Východní Jeruzalém byl mezinárodním společenstvím uznán hlavním městem státu Palestina podle hranic před událostmi roku 1967.

Rada bezpečnosti v návaznosti na prohlášení Spojených států amerických ve smyslu uznání Jeruzaléma jako celku hlavním městem státu Izrael dne 18. 12. 2017 hlasovala o (svou povahou právně závazné) rezoluci, která by odmítla takové uznání. Ačkoliv čtrnáct členů Rady bezpečnosti hlasovalo pro tuto rezoluci, nedošlo k jejímu přijetí z důvodu veta Spojených států amerických, stálého člena Rady bezpečnosti. K přijetí rezoluce Radou bezpečnosti je třeba většiny devíti hlasů zahrnující hlasy všech stálých členů, tedy jejich jednomyslnost. ${ }^{117} \mathrm{O}$ tři dny později, 21. 12. 2017 na zvláštní schůzi Valného shromáždění byla přijata rezoluce vyzývající k dodržování předchozích rezolucí stran statusu Jeruzaléma a dále apelující na státy, aby nepřistoupily ke stěhování svých zastupitelských úřadů z Tel Avivu do Jeruzaléma. Podle této rezoluce Valného shromáždění A/ES-10/L.22 má ke konečnému rozhodnutí o statusu Jeruzaléma dojít prostřednictvím jednání o konsensu mezi státy Izrael a Palestina v souladu s předchozími relevantními rezolucemi. ${ }^{118}$

$\mathrm{V}$ prŕípadě realizace přesunutí zastupitelských úřadů do Jeruzaléma kumulativně s aktem uznání Jeruzaléma hlavním městem Izraele by tedy v souladu s mezinárodním právem mělo být zřejmé výslovné prohlášení států o uznání toliko Západního Jeruzaléma hlavním městem Izraele. Je zřejmé, že v souladu s požadavkem respektování předchozích souvisejících rezolucí Rady bezpečnosti a Valného shromáždění by k rozdělení v souladu s mezinárodním právem mohlo dojít v prŕípadě respektování hranic před šestidenní válkou roku 1967, čímž by stát Izrael zcela pozbyl své pozice vojenské okupující mocnosti ve Východním Jeruzalémě a tím i svého (protiprávního) vlivu v historickém centru Starého města.

\footnotetext{
${ }^{116}$ Legal Consequences of the Construction of the Wall in the Occupied Palestinian Territory. Advisory Opinion, I. J. C. Reports 2004, s. 136.

117 ČEPELKA - ك̌STURMA, c. d., s. 491.

118 UNITED NATIONS. Resolution A/ES-10/L.22 „,Status of Jerusalem “ [online], 2017 [cit. 23. 12. 2018]. Dostupné na: http://undocs.org/A/ES-10/L.22.
} 


\section{ZÁVĚR}

Status Jeruzaléma je i nadále předmětem jednání mezi státem Izrael a Palestina a $\mathrm{v}$ prŕípadě, že by $\mathrm{k}$ předmětné dohodě do budoucna došlo, bylo by podstatné, aby tato dohoda byla též v souladu s mezinárodním právem. Závěrem je možné uvažovat o tom, jak by taková dohoda mohla př́ípadně upravit stávající poměry. Především nelze opomenout, že již od roku 2012 byl stát Palestina přijat jako nečlenský stát s pozorovatelským statusem na půdu OSN a došlo tím i k uznání Východního Jeruzaléma jako jeho hlavního města. ${ }^{119}$ Toto uznání, svou povahou spíše politického nežli právního charakteru, ovšem vylučuje možnost pro stát Izrael v souladu s právem vykonávat výlučnou teritoriální suverenitu vůči Jeruzalému jako celku, a tudíž znění izraelského základního zákona ve vztahu $\mathrm{k}$ jednotnému Jeruzalému jako hlavnímu městu Izraele lze považovat za neplatné bez ohledu na národní a historické zájmy státu Izrael. ${ }^{120}$ Pro uvedení faktického stavu do souladu s mezinárodním právem by měl stát Izrael uznat právní nárok státu Palestina na Východní Jeruzalém, tento nárok je navíc podpořený OSN, a též by mělo odpovídajícím způsobem dojít i ke změně znění př́islušného ustanovení základního zákona.

Problém by ovšem i nadále zůstal v př́ípadě historické části Starého města, které by se za daných okolností stalo součástí hlavního města státu Palestina. Stát Izrael má zajisté oprávněnou obavu, do jaké míry by byla zajištěna bezpečnost pro místní obyvatele i návštěvníky s ohledem na množství palestinských teroristických útoků namířených proti izraelským občanům i turistům. Je tedy možné, že z důvodu reálné bezpečnostní hrozby související se stále probíhajícím arabsko-izraelským konfliktem stát Izrael setrvává ve své roli, kdy nedbá právně závazných rezolucí Rady bezpečnosti. Na druhé straně ovšem tímto důvodem lze jen těžko obhájit výstavbu a rozšiřování izraelských sídlišs' ve Východním Jeruzalému za účelem zvýšení počtu židovských obyvatel Jeruzaléma.

V současné situaci se může jevit vhodnou in eventum např. částečná realizace původního plánu OSN v rezoluci 181 (II) na vytvoření mezinárodního režimu corpus separatum pro oblast historické části Starého města, např. dle vymezení jeho hranic městskými hradbami. Organizace spojených národů by takovou správu jistě mohla vykonávat s ohledem na ochranu kulturního dědictví lidstva a s respektováním práv náboženských skupin a tím i umožněním přistupu ke svatým místům židovského náboženství, kterými ve Starém městě jsou především Zed' nářků či Davidovo město, ke svatým místům křest’anského náboženství, krom ostatních např. místo poslední večeře Ježíše Krista či chrám Božího hrobu, a konečně ke svatým místům Islámu, především Skalnímu dómu a mešitě al-Aksá. Původní záměr rezoluce 181 (II) zahrnoval do režimu corpus separatum i oblasti vně Jeruzaléma, konkrétně Ein Karem, který je v dnešní době již městskou čtvrtí v západní části Jeruzaléma, a dále dle této rezoluce měl mezinárodní správě podléhat i Betlém, který se naopak nachází na okupovaném palestinském území.

119 UNITED NATIONS. General Assembly Resolution 67/19 Status of Palestine in the United Nations [online], 2012 [cit. 23. 12. 2018]. Dostupné na: https:/unispal.un.org/DPA/DPR/unispal.nsf/0/19862D03 C564FA2C85257ACB004EE69B.

${ }^{120}$ Srov. STATE OF ISRAEL. Basic Law: Jerusalem the Capital of Israel [online], 1980 [cit. 23. 12. 2018]. Dostupné na: http://knesset.gov.il/laws/special/eng/BasicLawJerusalem.pdf. 
Eventuální realizace mezinárodní správy Starého města či Jeruzaléma jako celku OSN by ovšem byla podmíněna souhlasem všech zúčastněných stran. $V$ současné době však není z jednání států Izrael a Palestina patrné, že by byly ochotné byt' jen jednat o takovém kompromisním řešení. Př́ípadné, ač v současnosti velmi nepravděpodobné, uzavření dohody o předložení žádosti o mezinárodní správu Jeruzaléma vykonávanou OSN by bylo toliko prvním krokem $\mathrm{k}$ uspořádání poměrů a bylo by nezbytné, aby následovala řada dalších jednání. Předmětem těchto jednání by bylo nalezení řešení či konsenzu např. v otázkách usídlení izraelských civilistů ve Východním Jeruzalémě a přilehlých osadách vystavených státem Izrael v rozporu s mezinárodním právem na okupovaném území. Dále by bylo nutné jednat o odstranění minimálně té části zdi, která prochází Východním Jeruzalémem. Tento krok by mohl být př́inosný především z důvodu iniciace uvedení současné protiprávní situace ${ }^{121}$ do souladu s mezinárodním právem.

Další in eventum možnou variantou by mohlo být i vytvoření dohody mezi izraelskou a palestinskou stranou o vytvoření režimu sdíleného hlavního města Jeruzaléma, pakliže by tento koncept též získal podporu OSN. Vedle rozdělení teritoriální suverenity vůči jednotlivým částem Jeruzaléma a vytvoření režimu vůči sdílené části Jeruzaléma by předmětem této dohody měla být i realizace spravedlivého a rovnoměrného rozložení vlivu a spolupráce krom ostatního při společném zajištění bezpečnosti ve Starém městě a na dalších památkách nacházejících se na palestinském území.

Pakliže by v průběhu roku 2019 a let nadcházejících mělo dojít k přesunu zastupitelských úřadů států z Tel Avivu do Jeruzaléma společně s aktem uznání Jeruzaléma hlavním městem Izraele, je dle mezinárodního práva nezbytné, aby tyto státy současně uznaly, že Jeruzalém je také hlavním městem státu Palestina. ${ }^{122}$

Mgr. Veronika D’Evereux

Právnická fakulta Univerzity Karlovy

devereuv@prf.cuni.cz

${ }^{121}$ Legal Consequences of the Construction of the Wall in the Occupied Palestinian Territory. Advisory Opinion, I. J. C. Reports 2004, s. 136.

122 BÍLKOVÁ, c. d. 